\title{
BIOLOGICAL DEVELOPMENT AND GROWTH OF AMUR CATFISH, Silurus asotus REARED UNDER CONTROLLED TROPICAL CONDITION
}

\author{
SITI UMEY SYAHIRAH MAT NAWANG ${ }^{1}$, CHING FUI FUI ${ }^{1 *}$ \\ and SHIGEHARU SENOO ${ }^{2}$ \\ ${ }^{1}$ Borneo Marine Research Institute, Universiti Malaysia Sabah, Jalan UMS, 88400, \\ Kota Kinabalu, Sabah, Malaysia \\ ${ }^{2} U M S-K i n d a i$ Aquaculture Development Center, Kindai University, \\ Shirahama, Wakayama, 649-2211, Japan \\ *E-mail: cfuifui@ums.edu.my
}

Accepted 25 October 2020, Published online 31 December 2020

\begin{abstract}
This study was conducted to investigate the biological development and growth of the Amur catfish, Silurus asotuss at the early larval stage. The eggs and larvae were obtained via the artificial spawning technique. The findings showed that the eggs of the Amur catfish hatched $27 \mathrm{hr}$ after fertilization (hAF) under temperature conditions of $26.9 \pm 1.3^{\circ} \mathrm{C}$. The newly hatched larvae $(4.71 \pm 0.87 \mathrm{~mm})$ had a large green yolk sac $\left(0.99 \pm 0.02 \mathrm{~mm}^{3}\right)$, unpigmented eyes, undeveloped mouth, and closed anus with one pair of developed maxillary barbels. At the $30 \mathrm{hAH}(7.01 \pm 0.41 \mathrm{~mm})$, the yolk sac continued to decrease $\left(0.33 \pm 0.08 \mathrm{~mm}^{3}\right)$, the barbels elongated, the mouth opened, the lower jaw was movable, with the peristaltic movement of the small intestine detectable. At this point, the larvae started to feed on rotifer and formulated feed. At $72 \mathrm{hAH}, 1$ arvae $(9.02$ $\pm 0.86 \mathrm{~mm})$ had developed pectoral and dorsal fin and at $12 \mathrm{dAH}(34.10 \pm 0.89 \mathrm{~mm})$ and entered the juvenile stage. This study concluded that the larval development and growth of the Amur catfish is relatively comparable to other tropical catfishes hence similar rearing techniques can be adopted to enhance the overall growth performance at the later stages.
\end{abstract}

Key words: Amur catfish, larval stages, growth performance, morphological development, nutritional transition period

\section{INTRODUCTION}

The Amur catfish (Silurus asotus, Linnaeus, 1758), a freshwater fish species originated from Japan and widely spread across East Asian countries, such as Vietnam, Korea, China, and Taiwan (Kim et al., 2005) that value as a food fish, and as a sport fish. This species is also known as the Far Eastern catfish (Gill et al., 2017), Japanese catfish, and Chinese catfish (Huckstorf, 2012). The Amur catfish is a carnivorous species belonging to the family of Siluridae (Yang et al., 2015).

There are many beneficial features associated with the Amur catfish, which makes it a viable aquaculture species. This species is a popular source of protein in Indo-China, Vietnam, Mongolia, and Japan (Kim et al., 2001), as many have claimed that

\footnotetext{
* To whom correspondence should be addressed.
}

they are delicious, and highly nutritious (Park et al., 2004). According to Huckstorf (2012), the production of wild Amur catfish in Vietnam is relatively high, and they are harvested throughout the year from their natural habitat (Gill et al., 2017). This species is also highly resistant to diseases, as it can survive from wounds, and has a maximum 12-year life span (Dulmaa, 1999). This species is commonly found in reservoirs, lakes, and mediumsized streams, as well as rivers with slow running water, and muddy bottoms.

The Amur catfish was introduced in Malaysia three years ago through research collaboration between Universiti Malaysia Sabah (UMS) and Kindai University, Japan. The import permits solely for research of this species were granted by the Sabah state of Fisheries Department in 2016. Understanding the fundamentals associated with larval development and growth is a major concern in developing a suitable protocol for breeding the 
Amur catfish. Breeding of this species was successfully achieved through natural and artificial spawning methods, but a stable mass seed production is yet to be established due to unknown mortality rates at the early larval stage (Baras, 1999). With the establishment of an elaborate breeding technique for this species, attempts to develop such techniques by understanding the fundamental biological aspects of the early larval development stages of the Amur catfish is critically necessary.

It is important to have a clear understanding of the embryonic and larval development of fish species, particularly in the areas of morphological and organ development (Borcato et al., 2004). Embryology and larval development in cultured fishes are important and evident in aquaculture practices, and fish breeding programs (Meijide \& Guerrero, 2000). The key to increasing larval growth and maximizing survival is important to help drive the needs of each larval stage. The larval stage can be divided into two phases, which are the pre-larval and post-larval stages (Cloutier et al., 2011). The pre-larval stage starts from the egg to the end of the absorption of the yolk sac. The post-larval stage starts after the absorption is completed to the end of the metamorphosis. The length of the time changes from species to species. It varies according to species, by shape, size, body ratio, fin size, pigmentation across different sizes and orders, shape, and time of the organ formation in the postlarval stage (Aral et al., 2011). Thus, information on the early larval stage of the fishes is needed for increasing the larval growth and maximizing survival.

The morphological studies are needed to help the observation of physical changes in the body of fishes that comprises of the total length, yolk sac absorption, and fin formation. Changes in the morphometry can be used as indices for tissue mobilization and yolk utilization rates, providing inexpensive, real-time information about the relative larval conditions (Rogers \& Westin, 1981). Besides that, changes in the total length through endogenous feeding have been used historically as a relative measure of the yolk conversion efficiency and allowed researchers to understand the larval conditions (Watanabe et al., 1998). The Amur catfish had been studied in temperate Korea with temperatures 23 to $25^{\circ} \mathrm{C}$ in 2017 (Mun et al., 2017). The temperature usually fluctuation during the incubation phase affected the variation in the rates of the fish development in the embryonic, larval, and juvenile stages. Hence, it is important to understand the fundamentals associated with larval morphological development studies to develop proper breeding protocols for the Amur catfish, especially in a tropical area. To develop the proper breeding protocols for the Amur catfish, the growth and morphological development of the Amur catfish larval needs to be determined initially. This study aims to determine the growth and development morphological characteristics of the early larval stages of the Amur catfish in tropical conditions.

\section{MATERIALS AND METHODS}

This study was conducted in the fish hatchery at UMS, Sabah in the green water environment. The brood fish of the Amur catfish used in this study were bred for three years in 20 tonnes of cylindrical fiber reinforced plastic (FRP; $4 \mathrm{~m}$ in diameter and $1 \mathrm{~m}$ in height), equipped with aeration. The brood fish were fed with enriched prey fish (Sardinella sp.) daily until satiation. The water condition was maintained at a temperature of $26.7 \pm 1.3^{\circ} \mathrm{C}$, with dissolved oxygen $(6.5 \pm 0.3 \mathrm{mg} / \mathrm{L})$ and a controlled $\mathrm{pH}(6.8 \pm 0.4)$. In this experiment, the guidelines of care and handlings of laboratory animals were followed according to the Malaysian Animal Handling Code of Conduct and code of practice for the care and use of animals for scientific purposes.

\section{Stripping and fertilization}

For artificial stripping purposes, the brood fish ( 1 female and 3 male) weighing $314.20 \pm 48.06 \mathrm{~g}$ were treated with the pituitary gland (PG) hormone. The dosage was $5 \mathrm{mg} / \mathrm{kg}$ of the total body weight of the fish. Hormones were injected via intramuscular and after $6 \mathrm{hr}$, the eggs and sperms were collected at the peak of the ovulation. The total weight of the egg was $(60.0 \pm 1.9 \mathrm{~g})$. The fertilized eggs were greenish in color and oval in shape. The fertilized eggs were then spread into $60 \mathrm{~L}$ plastic tanks until hatching. The tank was equipped with a sufficient aeration supply $\left(8 \mathrm{~cm}^{3} / \mathrm{s}\right)$. The hatching was expected to be around $27 \mathrm{hr}$ after the fertilization occurred. $60 \mathrm{~L}$ of rectangular plastic tanks equipped with recirculating aquaculture systems (RAS) throughout the incubation period with a water temperature of $26.9 \pm 1.3^{\circ} \mathrm{C}$ and dissolved oxygen $(6.7 \pm 0.3 \mathrm{mg} / \mathrm{L})$ with a controlled $\mathrm{pH}$ of $7.0 \pm 0.4$ was used. The egg development was observed under a microscope (Compound light microscope, Omax, China).

\section{Larval rearing}

A total of 10,886 Amur catfish larvae were collected for 20 days after the eggs hatched in five $60 \mathrm{~L}$ plastic tanks equipped with RAS. The water quality was at a temperature of $27.0 \pm 1.3^{\circ} \mathrm{C}$, with a dissolved oxygen level of $6.6 \pm 0.3 \mathrm{mg} / \mathrm{L}$ and $\mathrm{pH}$ of $7.2 \pm 0.4$. Bottom cleaning was carried out and $20 \%$ of water was exchanged every day. Newly hatched larvae were fed with a combination of live 
feed such as Rotifer (Brachionus plicatilis) and Moina sp., and formulated pellets (Otohime, Nisshin Maru, Japan), following the schedule as shown in Figure 1. The larvae were fed up to six times per day until satiation. The number of mortality events was measured by counting the dead larval. The embryonic (fertilization rate (\%), development rate $(\%)$, and hatching rate (\%)) were simply done by sampled $200 \pm 5$ eggs in a petri dish and calculated according to Fukuhara (1986). The larval data also was measured as follows according to Fukuhara (1986):

Fertilization rate $(\%)=\frac{\text { Total number of fertilized eggs }}{\text { Total number of eggs }} \times 100$

Development rate $(\%)=\frac{\text { Total number of survived eggs }}{\text { Total number of fertilized eggs }} \times 100$

Hatching rate $(\%)=\frac{\text { Total number of larvae hatched }}{\text { Total number of fertilized eggs }} \times 100$

Survival $(\%)=\frac{\text { Final number of fish }}{\text { Initial number of fish }} \times 100$

Mortality $(\%)=\frac{\text { Final number of fish died }}{\text { Initial number of fish }} \times 100$

\section{Larval morphological observation}

Once the embryonic development stage was completed, sampling $(n=10)$ was done for larval morphological observation. The hatching time was recorded and indicated as $0 \mathrm{hAH}$. The observation for larval development was sampled every $6 \mathrm{hr}$ interval from 0 until $90 \mathrm{hAH}$. After that, larvae continued sampled from 5 until $20 \mathrm{dAH}$ with 1 and 2 days intervals. The larvae were observed under a microscope (Compound light microscope, Omax, China) with a magnification of $40 x$ to examine the morphological development. The morphological changes that were observed included fins developed, mouth and anus opening, the appearance of the barbels, and pigmented eyes. All photos were taken using a digital camera and sketched. The larvae were then measured for their total length, and the yolk sac absorption using a microscope (Digital microscope, Dino-lite, Taiwan). The formula for yolk sac volume (YSV) was measured as follows according to Fukuhara (1986):

$\mathrm{YSV}=\frac{\pi}{6} \times \mathrm{L} \times \mathrm{H}^{2}$

L: Yolk sac length

$\mathrm{H}$ : Yolk sac height

\section{RESULTS}

\section{Embryonic observation}

A total of 14,400 eggs $(1.6 \pm 0.1 \mathrm{~mm})$ were collected and were found to be greenish, with negative buoyancy, sinking to the bottom of the tank. Fertilization and development rates were recorded at $90.0 \pm 4.9 \%$ and $80.0 \pm 4.9 \%$, respectively. The larval hatching rate was $75.6 \pm$ $4.7 \%$. The water temperature, dissolved oxygen, and $\mathrm{pH}$ during egg incubation ranged between $27.9 \pm$ $1.4^{\circ} \mathrm{C}, 6.5 \pm 0.5 \mathrm{mg} / \mathrm{L}$, and $7.1 \pm 0.4$, respectively. Hatching took place at approximately $27 \mathrm{hAF}$.

\section{Yolk sac absorption and larval growth}

The initial volume of the yolk sac for the newly hatched $(0 \mathrm{hAH})$ was observed at $0.99 \pm 0.02 \mathrm{~mm}^{3}$ and decreased to $0.90 \pm 0.13,0.77 \pm 0.05$, and 0.65 $\pm 0.15 \mathrm{~mm}^{3}$ at 6,12 , and $18 \mathrm{hAH}$, respectively. After that, the yolk sac volume decreased gradually to $0.47 \pm 0.03$ and $0.33 \pm 0.08 \mathrm{~mm}^{3}$ at 24 and $30 \mathrm{hAH}$. The first feeding time occurred at $30 \mathrm{hAH}$ while, the yolk sac volume was still visible and decreased at

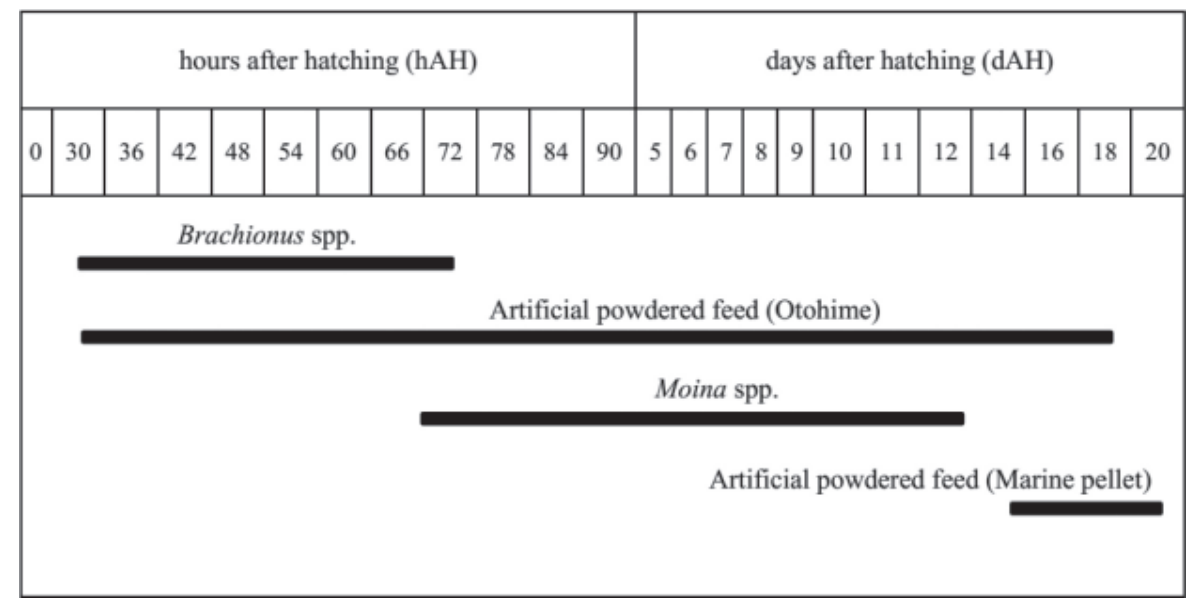

Fig. 1. Feeding regime of Amur catfish larvae for 20 days. 
$0.29 \pm 0.04,0.22 \pm 0.06,0.19 \pm 0.10,0.14 \pm 0.09$, $0.10 \pm 0.01$ and $0.0 \mathrm{~mm}^{3}$ at 36, 42, 48, 54, 60 and $66 \mathrm{hAH}$, respectively. The yolk sac was completely exhausted at $66 \mathrm{hAH}$. The nutritional transition period (NTP) of the Amur catfish was $36 \mathrm{hr}$ (Figure 2).

The total length $(\mathrm{mm})$ of the newly hatched larvae $(0 \mathrm{hAH})$ was $4.71 \pm 0.87 \mathrm{~mm}$, reaching 5.51 $\pm 0.25,5.57 \pm 0.25$ and $5.86 \pm 0.70 \mathrm{~mm}$ at 6,12 and $18 \mathrm{hAH}$ (Figure 3). After that, the total length of the Amur catfish increased slightly to $6.44 \pm 0.69$ and $7.01 \pm 0.24 \mathrm{~mm}$ at 24 and $30 \mathrm{hAH}$. The total length increased steadily at $7.26 \pm 0.41,7.48 \pm 0.05$ and finally $7.82 \pm 0.37 \mathrm{~mm}$ at 36,42 and $48 \mathrm{hAH}$, respectively. Then, the total length of the Amur catfish increased slightly to $7.85 \pm 0.99,8.32 \pm 0.51$,
$8.90 \pm 0.46,9.02 \pm 0.86,9.27 \pm 0.32,9.90 \pm 0.26$ and $11.78 \pm 0.41 \mathrm{~mm}$ at $54,60,66,72,78,84$ and $90 \mathrm{hAH}$, respectively. The total length increased steadily at $12.12 \pm 0.68,13.48 \pm 0.16,15.02 \pm 0.45$, $15.47 \pm 0.13,16.09 \pm 0.64,16.65 \pm 0.11,18.35 \pm$ 0.04 and finally $20.22 \pm 0.09 \mathrm{~mm}$ at $5,6,7,8,9$, 10,11 and $12 \mathrm{dAH}$, respectively. After that, total length increased at 14, 16, 18 and $20 \mathrm{dAH}$ with $23.28 \pm 0.13,26.44 \pm 0.17,30.52 \pm 0.50$ and 34.10 $\pm 0.89 \mathrm{~mm}$, respectively.

\section{Larval survival and mortality}

All Amur catfish larvae attained $100.0 \pm 0.0 \%$ survival at 0 and $6 \mathrm{hAH}$ (Figure 4). After that, the survival of larvae decreased gradually to $99.9 \pm 0.2$, $99.9 \pm 0.1,99.9 \pm 0.17,99.8 \pm 0.6$ and $99.4 \pm 0.2 \%$

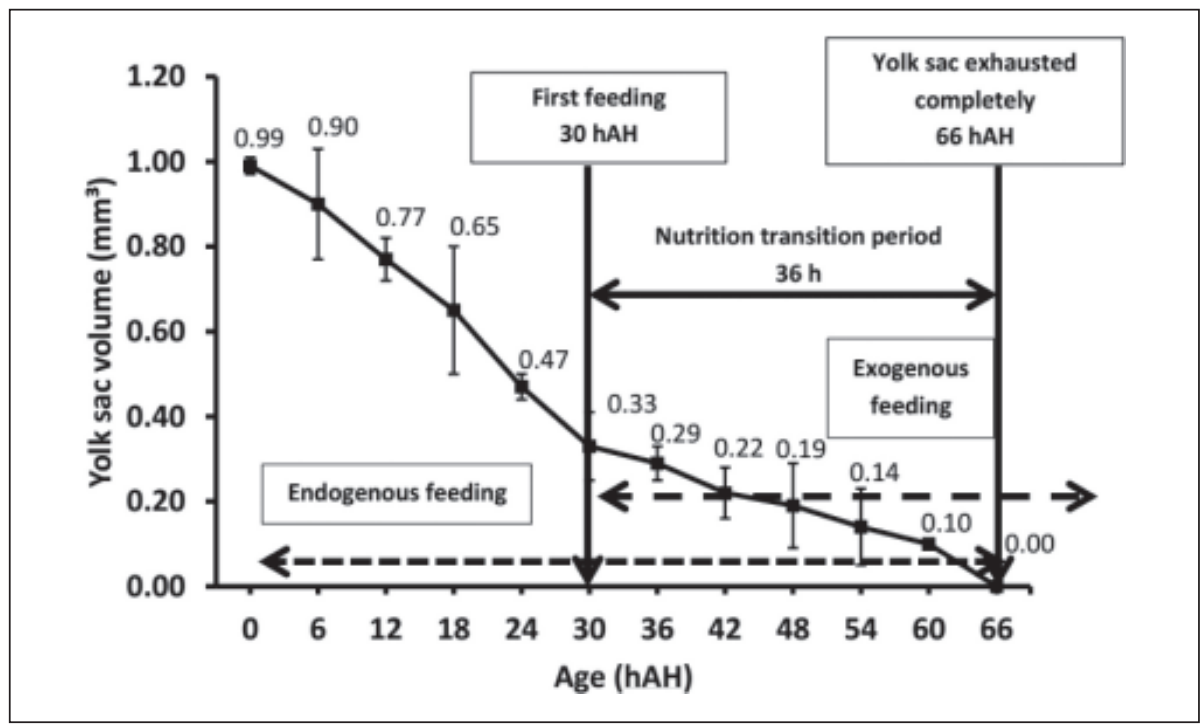

Fig. 2. Yolk sac volume $\left(\mathrm{mm}^{3}\right)$ of Amur catfish from 0 until $66 \mathrm{hAH}$. First feeding started from $30 \mathrm{hAH}$ and yolk sac completely exhausted at $66 \mathrm{hAH}$ with $36 \mathrm{hr}$ NTP.

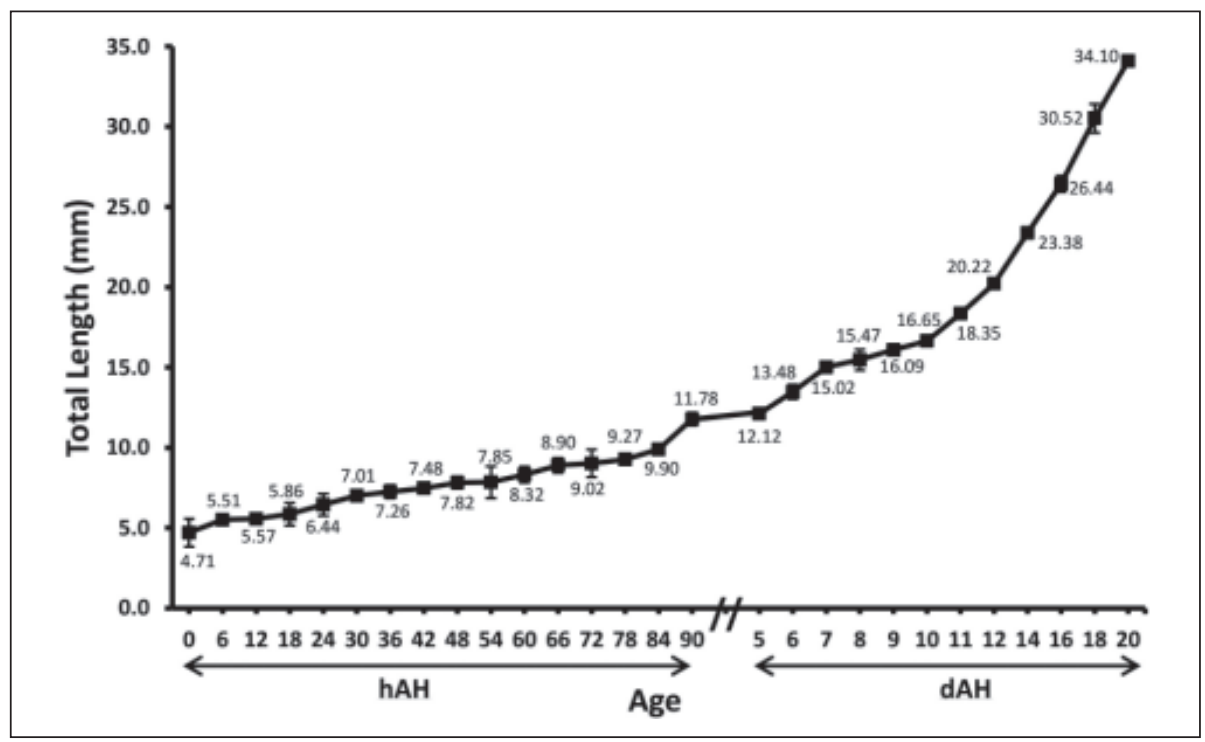

Fig. 3. Growth changes in total length $(\mathrm{mm})$ of Amur catfish from $0 \mathrm{hAH}$ to $20 \mathrm{dAH}$. 
at 12, 18, 24, 30 and $36 \mathrm{hAH}$, respectively. Survival of the Amur catfish continued to decrease at $99.0 \pm$ $0.3,99.0 \pm 0.1,98.9 \pm 0.2,98.5 \pm 0.4,98.3 \pm 0.3$, $98.0 \pm 0.3$ and $97.7 \pm 0.2 \%$ at $42,48,54,60,66,72$ and $78 \mathrm{hAH}$, respectively. At $84 \mathrm{hAH}$, the larvae attained $97.3 \pm 0.3 \%$ survival, and finally decreased to $97.0 \pm 0.1 \%$ of survival at $90 \mathrm{hAH}$. Then, the survival of Amur catfish continue decreased to $96.5 \pm 0.3,96.3 \pm 0.3,96.0 \pm 0.1,95.8 \pm 0.1,95.5 \pm$ $0.2,95.3 \pm 0.2$ and $95.2 \pm 0.3 \%$ at $5,6,7,8,9,10$ and $11 \mathrm{dAH}$, respectively. After that, the survival of larvae decreased gradually to $95.2 \pm 0.1,95.0 \pm 0.2$, $94.7 \pm 0.2,94.3 \pm 0.1$ and $94.0 \pm 0.2 \%$ at 12,14 , 16,18 and $20 \mathrm{dAH}$, respectively.
The mortality of the Amur catfish larvae are shown in Figure 5. Mortality was first observed at $12 \mathrm{hAH}$ with $0.1 \pm 0.0 \%$. At $18,24,30,36,42$ and $48 \mathrm{hAH}$, mortality rates increased with $0.1 \pm 0.0$, $0.1 \pm 0.0,0.2 \pm 0.01,0.6 \pm 0.01,1.0 \pm 0.05$ and 1.0 $\pm 0.03 \%$, respectively. Mortality attained $1.1 \pm 0.04$, $1.5 \pm 0.02,1.7 \pm 0.04,2.0 \pm 0.01,2.3 \pm 0.03,2.7 \pm$ 0.04 and $3.0 \pm 0.05 \%$ at $54,60,66,72,78,84$ and $90 \mathrm{hAH}$, respectively. At 5, 6, 7, 8, 9, 10 and 11 $\mathrm{dAH}$, the mortality incidence increased slightly at $3.5 \pm 0.02,3.7 \pm 0.05,4.0 \pm 0.01,4.2 \pm 0.04,4.5 \pm$ $0.07,4.7 \pm 0.05$ and $4.8 \pm 0.02 \%$. After that, the mortality of the larvae increased slightly at $4.8 \pm$ $0.06,5.0 \pm 0.01,5.3 \pm 0.01,5.7 \pm 0.01$ and $6.0 \pm$ $0.01 \%$, at $12,14,16,18$ and $20 \mathrm{dAH}$, respectively.

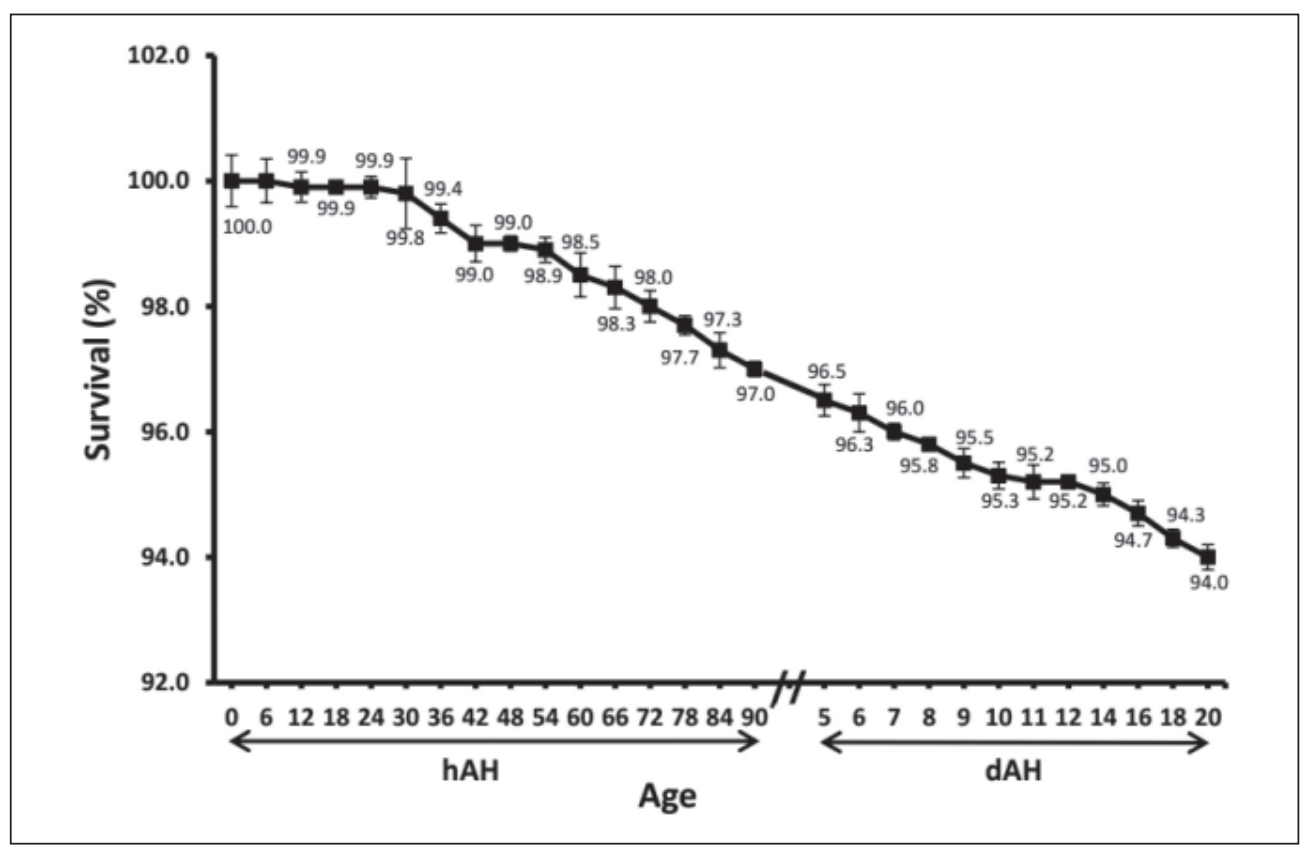

Fig. 4. Survival (\%) of Amur catfish from 0 hAH to $20 \mathrm{dAH}$.



Fig. 5. Mortality (\%) of Amur catfish from 0 hAH to $20 \mathrm{dAH}$. 
A


I
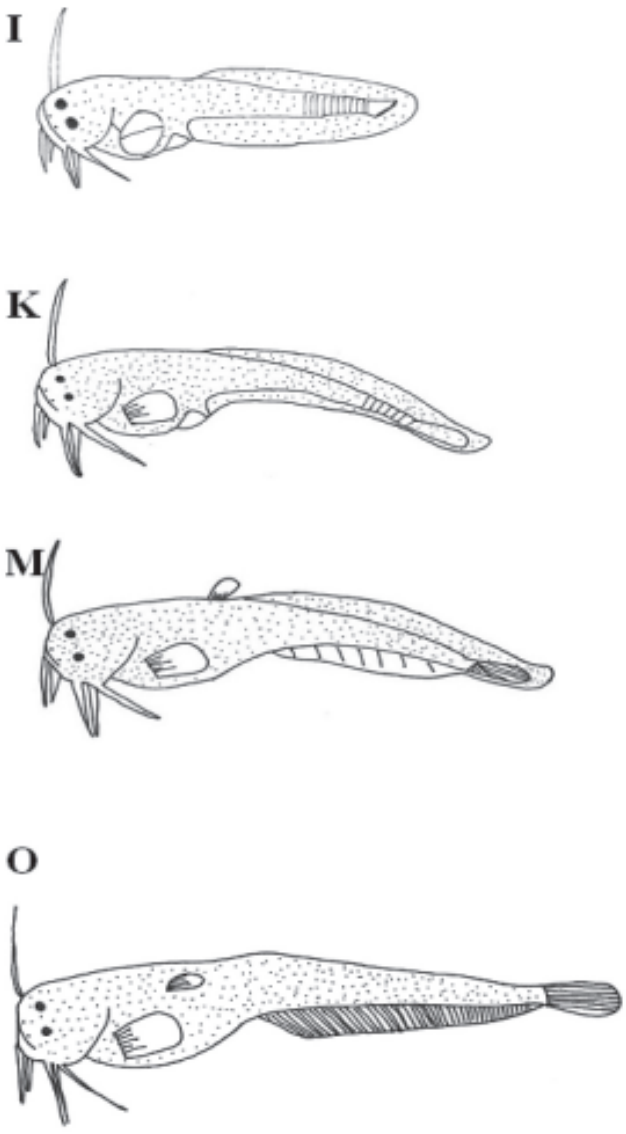
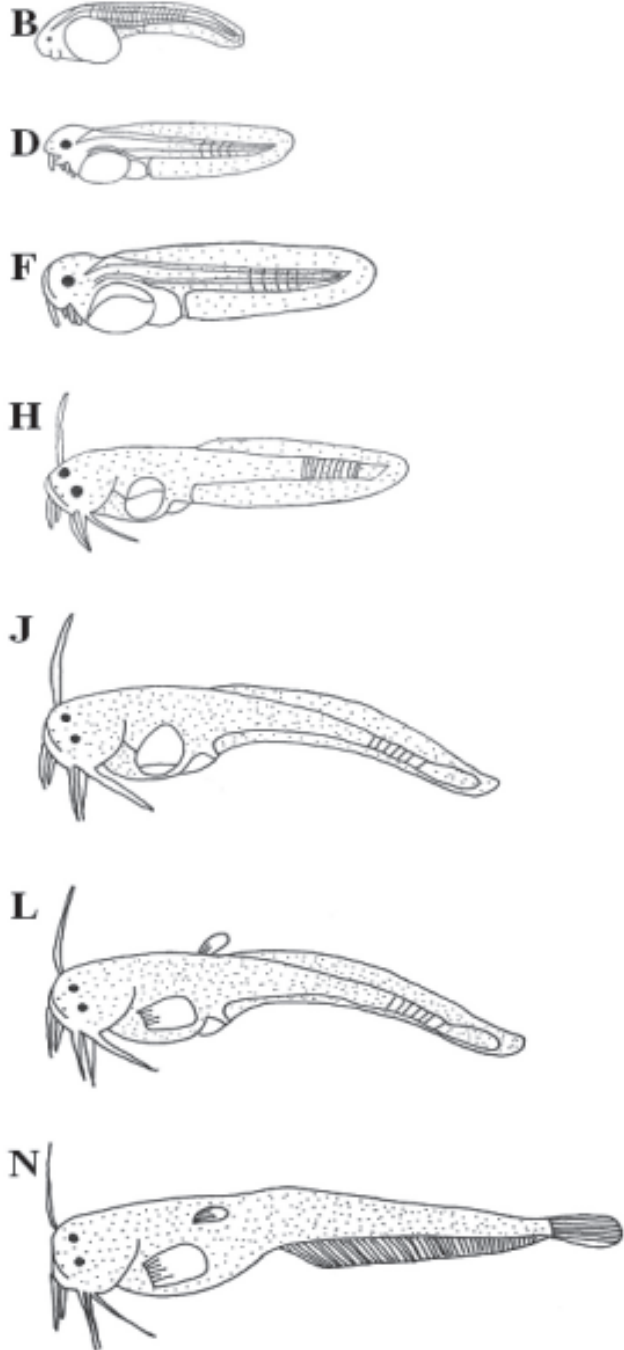

$\mathbf{P}$

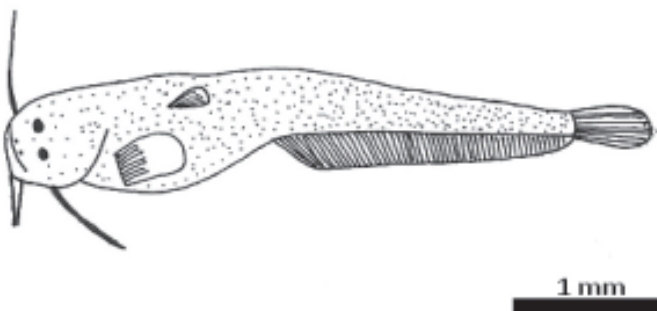

Fig. 6. Morphological ontogeny in the Amur catfish larvae. A) 0 hAH; B) 6 hAH; C) 12 hAH; D) 18 hAH; E) 24 hAH; F) 30 hAH; G) 36 hAH; H) 42 hAH; I) 48 hAH; J) 60 hAH; K) 66 hAH; L) 72 hAH; M) 5 dAH; N) 9 dAH; O) 12 dAH; P) 20 dAH (Bar: $1 \mathrm{~mm})$.

\section{Larval morphological development}

The morphological changes to the Amur catfish larvae are illustrated in Figure 6. Newly hatched larvae had a large visible greenish yolk sac, unpigmented eyes, mouth and anus which was not open, and one pair of maxillary barbels. At this stage, the pigmentation on the body started to appear (Figure 6A). At $6 \mathrm{hAH}$, the eyes were pigmented, and the anus started to develop, and the yolk sac decreased in size (Figure 6B). At 12 $\mathrm{hAH}$, the eyes of larvae were deeply pigmented, the mouth and anus were open, and one pair of the mandibular barbels had developed (Figure 6C). The pigmentation on the body increased at this stage. 
At 18 and $24 \mathrm{hAH}$, the yolk sac of the Amur catfish larvae decreased, and the barbels became much longer (Figures 6D and 6E).

At $30 \mathrm{hAH}$, the barbels become longer and there were four barbels, and the yolk sac decreased. The larvae had a mouth that was opened, and the lower jaw was movable (Figure 6F). The larvae were observed to be morphologically prepared for the first feeding, and rotifer was observed as there was a peristaltic movement of the small intestine. At 36 $\mathrm{hAH}$, the larvae had another pair of mandibular barbels (Figure 6G). At $42 \mathrm{hAH}$, black pigmentation became more obvious. Six barbels appeared around the mouth, the mouth opening was more pronounced, and the lower jaw was movable (Figure $6 \mathrm{H})$. At $48 \mathrm{hAH}$, the larvae's body pigmentation increased. The upper and lower jaws were fully developed (Figure 6I).

At $60 \mathrm{hAH}$, the tip of the tail started to bend at $45^{\circ}$, and pigmentation on the body more intense (Figure 6J) while at $66 \mathrm{hAH}$, the yolk sac finished, and pectoral fin in round shape appeared at the larvae body (Figure 6K). At $72 \mathrm{hAH}$, stem began to develop in the dorsal fin, and pectoral and dorsal fin appeared at the body (Figure 6L). At $5 \mathrm{dAH}$, larvae showed anal and pelvic fins appeared (Figure 6M), and at $9 \mathrm{dAH}$, caudal fin start developed and fin rays start to be seen at anal and caudal fin (Figure 6N). Amur catfish reached the juvenile stage as external morphology starts similarly with adult fish at $12 \mathrm{dAH}$ (Figure 6O). At $20 \mathrm{dAH}$, another one pair of mandibular barbels degenerates on Amur catfish fish (Figure 6P).

\section{DISCUSSION}

\section{Embryonic development of fertilized eggs}

The fertilized eggs of the Amur catfish were greenish, with a uniform spherical shape. Greenish eggs are a common indicator for many tropical catfishes eggs, and this can be a key identification to distinguish catfish from other freshwater fish species, such as the yellowish eggs of the river catfish (P. hypophthalmus) (Baidya \& Senoo, 2003) and bagrid catfish (M. nemurus) (Muchlisin, 2017). Meanwhile, it is evident that this species also has bigger egg diameters $(1.6 \pm 0.01 \mathrm{~mm})$ compared to other tropical catfish, such as the yellowtail catfish, Pangasius pangasius (1.2 until $1.45 \mathrm{~mm}$ ) (Ferosekhan et al., 2015) and the African catfish (Clarias gariepinus) measured 1.26 to $1.44 \mathrm{~mm}$ (Baidya \& Senoo, 2002).

The egg size could increase the potential for survival of the individual fish, as large larvae tend to have lower mortality rates, and can feed on larger prey, and swim actively and evidently. This should increase the larvae's resistance to starvation and, thereby, increase its probability of encountering a favorable environment (Duarte \& Alcaraz, 1989). According to McGurk (1986), bigger egg sizes could have a much bigger yolk sac of larvae, that provides sufficient feed in the endogenous stage, and longer nutritional transition periods, hence the larvae can have ample time to complete early development of the morphology and sensory organs. Eggs produced by one individual female tend to be more uniform in size, and that is also an indicator of the good quality of the eggs (Bagenal, 1969). The selection of good female broodstock for artificial spawning purposes was a critical factor that contributed to the uniform and good quality of the eggs in this study.

This study obtained good quality eggs through fertilization with a rate of $90.0 \pm 4.9 \%$, and a development rate of $80.0 \pm 4.9 \%$, as well as a hatching rate of $75.6 \pm 4.7 \%$. This contributes to the comprehensive broodstock management, such as strict monitoring of the quality of the water, extensive feeding management, and stressminimized handling techniques. A complete broodstock diet is necessary to improve spawning quality and consistency (Izquierdo et al., 2001). In the present study, broodstock of the Amur catfish was fed omega enriched prey fish (Sardinella sp.) to support maturation, and to later produce good quality eggs in the subsequent stages. The brood stockfish were usually were fed at $1-2 \%$ of their body weight per day, according to the FAO (2010). However, in this study, the Amur catfish were fed approximately $4-6 \%$ of their body weight to a satiation level to maximize the maturation quality of the broodstock, which later contributed to the availability and quality of the seeds in the subsequent stages of the fish seed production (Samad et al., 2013).

One of the most significant findings in this study revealed an extremely short larval hatching time at 27 hours $\left(27.9 \pm 1.4^{\circ} \mathrm{C}\right)$, compared to those reported by Mun et al. (2017) on similar fishes, of which, the Amur catfish took $48 \mathrm{hr}$ to hatch in Korea with lower water temperature (15.8 until $\left.26.7^{\circ} \mathrm{C}\right)$. Undoubtedly, the temperature was accountable for the significant difference in the hatching hour, of which, in this study, the larvae hatched in warmer waters, which presumably has a much higher induced metabolic rate to hatch. Temperature is a major abiotic factor for controlling the rate of morphogenesis in fish. This would be beneficial to producing Amur catfishes with temperatures above $27^{\circ} \mathrm{C}$, as the time to hatch can be shortened when incubated at this temperature. This finding has shown that the production of Amur catfishes can also be performed continuously all year round, in tropical regions, owing to the stable and high temperatures between 27 to $28^{\circ} \mathrm{C}$. A previous study by Haylor and Mollah (1995) showed that African 
catfish eggs can be successfully hatched in ambient water temperatures between 20 and $35^{\circ} \mathrm{C}$ with different hatching times.

\section{Growth of Amur catfish larvae}

The total length of the newly hatched larvae of the Amur catfish was $4.71 \pm 0.87 \mathrm{~mm}$ and grew to $34.10 \pm 0.89 \mathrm{~mm}$ at $20 \mathrm{dAH}$. Hence, this can be categorized as a fast-growth species. Contradicting the study reported by Mun et al. (2017), this showed that a similar species was only $3.60 \mathrm{~mm}$ upon hatching, and increased to $8.00 \mathrm{~mm}$ at $72 \mathrm{hAH}$, with a temperate of 23 to $25^{\circ} \mathrm{C}$ in Korea. The temperature fluctuation during the incubation phase affected the variation in the rates of fish development in the embryonic, larval, and juvenile stages. A decrease in the rate of ontogeny caused by a change in temperature that resulted in a much longer larval time and increased exposure to the larval environment was observed (Atkinson, 1996). Temperatures can influence the size of the organism, at which ontogenetic transformation occurs, such as physiological and behavioral capabilities of an organism, which can exhibit effects of a changing environment (Rijnsdrop et al., 2009).

Small temperature changes could have an excessively greater impact on the development of tropical fish larvae, than larvae intemperate systems with naturally large temperature variations (Green $\&$ Fisher, 2004). In tropical regions where water temperatures lie between 27 to $28^{\circ} \mathrm{C}$, catfish larval sizes are much larger, as obtained in this study. This was observed for the African catfish $(4.50 \pm 0.20$ $\mathrm{mm}$ in total length) (Mukai et al., 2008). Swimming speed and behavior are an example of performance capabilities, as it is important to dispersal, prey capture, and predator avoidance. Temperature affects the swimming speed and activity which can influence the growth and morphological changes (Green \& Fisher, 2004). In the present study, the Amur catfish swam vertically and horizontally in the middle layer of the water column and swam for most of the period on the bottom during the daytime. They swam throughout the surface and middle layers more actively at night time, which they are categorized as nocturnal species. Therefore, less energy may be required for fishes that allow for an increase in protein and fat deposition in the fish bred in the tank (Mat Nawang et al., 2019). This might be the factor that is responsible for the improved growth of the Amur catfish.

\section{First feeding of Amur catfish larvae}

The onset of the first feeding was observed at $30 \mathrm{hAH}$, as was similarly reported in some catfishes, such as the bagrid catfish (30 hAH) (Rahmah et al., 2011) and the African catfish (36 hAH) (Baidya \& Senoo, 2004). Amur catfishes were able to attain successful initiation of the first feeding when the rotifer was introduced in the breeding tank, creating larvae with completely pigmented eyes, open mouths, movable lower jaws, intestines that depicted peristaltic movement, and an open anus. A similar study reported the use of rotifer to compensate for delays in successful initiation of first feeding for catfish fish larvae, such as the African catfish (Ing \& Chew, 2015), freshwater carp, Cyprinus carpio (Lubzens et al., 1984), and sutchi catfish, P. hypophthalmus (Mukai et al., 2010).

In the present study, the yolk sac volume of the newly hatched Amur catfish larvae was $0.99 \pm 0.02$ $\mathrm{mm}^{3}$. Larvae hatched from larger eggs tend to prolong the onset of exogenous feeding (Gisbert et al., 2000). According to Ching et al. (2012), smaller sized larvae possed a smaller yolk sac, and could only provide endogenous feeding in a short period. Thus, the larvae experienced a shorter time to change from endogenous to exogenous feeding and potentially underwent shorter yolk sac absorption. First feeding periods of the Amur catfish larvae ranged from 30 to $66 \mathrm{hAH}$, with the yolk sac remaining at $78.3 \%$ of its initial volume, and had $36 \mathrm{hr}$ NTP. Therefore, the short yolk sac absorption was disadvantageous for larval survival and growth strategies at the early stage, as larvae had insufficient time to develop their feeding ability, and physiological mechanisms, before first feeding (Kailasam et al., 2007).

The size, age, and condition of the broodstock increased the egg size, as larger eggs with larger yolk sacs generally yielded offspring with a higher probability of survival (Puvaneswari et al., 2009). Commonly, larval yolk sac absorption rates varied according to the species (Jordaan \& Kling, 2003), salinity (Swanson, 2005), temperature (Berlinsky et al., 2004), and first feeding time (Yoseda et al., 2006). The Amur catfish in temperate regions such as Korea was recorded to initiate first feeding at $3 \mathrm{dAH}$ with Artemia sp. when the yolk sac was completely absorbed (Mun et al., 2017). The length of time from hatching to first feeding depended upon the nutrients stored in the yolk sac (Hodson \& Blunt, 1986), and environmental factors (Houde, 1974). First feeding of the larvae tilapia (Tilapia sparmanii) started as the water temperature decreased. Feeding started on day 2 at $30^{\circ} \mathrm{C}$, on day 3 at $27^{\circ} \mathrm{C}$, and day 6 at $24^{\circ} \mathrm{C}$ (Ishibashi, 1974). The nutritional period, which started from endogenous nutrient supply from the yolk to the exogenous feeding on its prey is a very important stage in the early larval development.

\section{Survival and mortality of Amur catfish larvae}

Survival of the Amur catfish showed a decreased pattern of survival from $6 \mathrm{hAH}$ to $20 \mathrm{dAH}$, with 100 to $94 \%$, which is commonly seen in many other fish 
species. The present study also showed an increased pattern of mortality, from $6 \mathrm{hAH}$ to $20 \mathrm{dAH}$ ranging from 0 to $6 \%$ mortality. Many factors can influence the larval survival and mortality rates, such as nutrients stored, and the size of the yolk sac, temperature, size heterogeneity, food density, light intensity, and time of the first feeding (Dou et al., 2002). In this study, cannibalism was responsible for larval survival and mortality rates, since the larvae had cannibalistic behavior.

One of the factors that influenced the cannibalism of fishes depends on the stocking density and size heterogeneity. Furthermore, insufficient food that is supplied in the culture system leads to decreased survival of the larval and increased mortality rates. The absence of sufficient food may lead to stress of the larval, which leads to cannibalism in the culture system. On the other hand, a work by Mollah et al. (1999) reported that the African catfish cannibalism can be reduced by regular grading in the larval rearing system. The Asian catfish ( $P$. hypophthalmus) showed heavier losses of larval caused by the temperature and cultured fishes at suitable temperatures, which can maximize the larval growth and survival rates. Unsuitable temperatures might also induce deformation in the larval stages, including the commonly found absence of pectoral fins, which avoids the fish from moving backward (Baras et al., 2011).

\section{Morphological development of Amur catfish larvae}

Newly hatched larvae developed maxillary barbels (one pair barbel) at $0 \mathrm{hAH}$, and this was similarly reported for newly hatched larvae of the bagrid catfish, which first appeared with adhesive characteristics (Ooi, 2010). Furthermore, the development of the first pair mandibular barbel for the Amur catfish was at $12 \mathrm{hAH}$, and continued to a second pair mandibular barbel at $36 \mathrm{hAH}$. The mandibular barbels functioned as gustatory senses for feeding during the early larval stages. The Amur catfish had fully pigmented eyes at $6 \mathrm{hAH}$, and this early development, in particular, the larval eyes, was in agreement with Mun et al. (2017), who stated that the demersal egg's larvae, like the Amur catfish, developed eyes and others organ much quicker, compared to the pelagic larvae. This is undoubtedly beneficial, as it is an improvement to how predators can be alluded to due to the early maturation of the visual system, as well as the improvement in the mobility itself (Brown, 1986). The formation of pigmentation in the eye provides a phototaxis negative reaction towards the light.

Newly hatched larvae are usually transparent, but some larvae have some visible pigment spots. Pigment spots are often used for species identi- fication, and the developmental patterns of various organs differ from species to species (Iwai, 1980). Pigmentation of the Amur catfish larvae starts to appear upon hatching, in which they are recorded much earlier than other catfish larvae. According to Iwai (1980), the bagrid catfish larvae depicted pigmentation at $12 \mathrm{hAH}$ on the head and yolk sac surfaces. This characteristic can be used to differentiate the Amur catfish and other catfishes, upon hatching. In terms of the taste buds development of the Amur catfish, it is found to be rather similar, as the taste buds increased in number and also in size, as the development is much faster in freshwater, compared to marine species. The taste buds appeared at 0,12 , and $36 \mathrm{hAH}$ in the Amur catfish, which was before the onset of the first feeding, although it is considered as a rather preliminary form of the taste buds. Taste buds play an important role in fishes to detect and distinguish different kinds of chemical compounds, and this further justifies the active prey detection for the Amur catfish in the early stages. This behavior is similarly seen in the larval of the African catfish, which showed a feeding frenzy when they were stimulated with the rotifer, even before the development of the taste buds (Mukai et al., 2008).

The Amur catfish was not able to commence its first feeding until the lower jaw was fully developed, although the mouth was open much earlier. The Amur catfish was seen with an open mouth at $12 \mathrm{hAH}$, but the lower jaw was only functional at $30 \mathrm{hAH}$. The anus started to open around this period, and hence, the first feeding started. Ramezani-Fard et al. (2011) reported that the larval mouth of the Malaysian mahseer (Tor tambroides) was first seen opened with a functional lower jaw as early as $1 \mathrm{dAH}$. The mouth of the Amur catfish larvae opened with a size of $150 \mu \mathrm{m}$ at 30 $\mathrm{hAH}$. The mouth size determines the maximal and optimal prey size to be ingested by the fish larvae (Rønnestad et al., 2013). Fish larvae can ingest prey with similar sizes into its mouth, but they prefer smaller prey, as the preferred prey size increases as the mouth size increases (Tucker, 2000). In the present study, the Amur catfish were fed rotifer (100 to $400 \mu \mathrm{m}$ ) for the first feeding, and after $66 \mathrm{hAH}$, the Amur catfish were fed moina (500 to $1000 \mu \mathrm{m}$ ) and a grinded formulated pellet (Otohime, Nisshin Maru, Japan). If the feed provided is larger than the mouth size, the larvae will certainly be unable to feed, and consequently die of starvation (Qin \& Hiller, 2000). Thus, it is suggested that the feed needs to be offered according to the mouth size of the Amur catfish larvae.

The pectoral fin of Amur catfish starts developed in round shape at $66 \mathrm{hAH}$ that function as help to steer and control depth (Puvaneswari et al., 2009). After that, at $72 \mathrm{hAH}$, pectoral and 
dorsal fin appeared at the body with the right shape of the fin. Dorsal and anal fin produce balancing torques during steady swimming (Standen \& Lauder, 2005). The anal and pelvic fin appeared at the body at $5 \mathrm{dAH}$. Pelvic fin function as stabilizing and stopping when larvae swimming (Puvaneswari et al., 2009). Caudal fin appeared at $9 \mathrm{dAH}$, and fin rays start to develop on the anal and caudal fin. The development of the extended caudal fin can aid in the active movement during prey capturing or predator escaping (Puvaneswari et al., 2009).

At $12 \mathrm{dAH}$, Amur catfish reached the juvenile stage as the morphology of the Amur catfish same as adult fish with a total length, $20.22 \pm 0.09 \mathrm{~mm}$. A similar study reported in Mun et al. (2017) that Amur catfish reached the juvenile stage at $12 \mathrm{dAH}$ with a total length, $16.7 \pm 0.35 \mathrm{~mm}$. One pair of mandibular barbels degenerates at $20 \mathrm{dAH}$ when the total length, $34.10 \pm 0.89 \mathrm{~mm}$, and called temporary barbels. Another one pair of mandibular and one pair of maxillary barbels possesses permanent. The regenerative ability of the barbels may diminish gradually according to the increase in the total length of the larvae. According to Sato and Katagiri (1966) showed that the regeneration of both permanent and temporary barbels of larvae in catfish species measuring 20 and $30 \mathrm{~mm}$ in total length, respectively.

\section{CONCLUSION}

In summary, the present study provided important information on the successful early larval breeding of the Amur catfish. Early larval development of the Amur catfish showed higher fertilization, development and hatching rates, and better growth rates, which was relatively comparable to other tropical catfishes. The Amur catfish also showed lower mortality with a suitable breeding protocol applied. The development of the morphology of the early larval stages provided possible improvement of the larvi-culture management for the Amur catfish. Further studies should be carried out, particularly to enhance the growth and survival rates of this species.

\section{ACKNOWLEDGEMENTS}

This study was funded through the UMSGreat Grant under the code GUG0316. The authors would like to thank all staff and research assistants of the Borneo Marine Research Institute, Universiti Malaysia Sabah in particular the Fish Hatchery and Kindai University, Japan for their technical assistance throughout the timeframe of the study.

\section{REFERENCES}

Aral, F., Şahýnöz, E. \& Doğu, Z. 2011. Embryonic and larval development of freshwater fish. In: Recent Advances in Fish Farms. F. Aral (Ed.). IntechOpen, pp. 83-94.

Atkinson, D. 1996. Ectotherm life-history responses to developmental temperature. In: Animals and Temperature: Phenotypic and Evolutionary Adaptation. I.A. Johnston (Ed.). Cambridge University Press, Cambridge, pp. 183-204.

Bagenal, T.B. 1969. The relationship between food supply and fecundity in brown trout Salmo trutta L. Journal of Fish Biology, 1: 167-182.

Baidya, A.P. \& Senoo, S. 2002. Observations of oocyte final maturation and eggs on African catfish Clarias gariepinus under artificial rearing conditions. Aquaculture Science, 50: 415-422.

Baidya, A.P. \& Senoo, S. 2003. Decline in fertilization and hatching rates of patin, Pangasius hypophthalmus after ovulation. Aquaculture Science, 51: 407-415.

Baidya, A.P. \& Senoo, S. 2004. Decline in fertilization and hatching rates of African catfish Clarias gariepinus after ovulation. Aquaculture Science, 52: 37-44.

Baras, E., Raynaud, T., Slembrouck, J., Caruso, D., Cochet, C. \& Legendre, M. 2011. Interactions between temperature and size on the growth, size heterogeneity, mortality and cannibalism in cultured larvae and juveniles of the Asian catfish, Pangasianodon hypophthalmus (Sauvage). Aquaculture Research, 42: 260-276.

Baras, E., Tissier, F., Philippart, J.C. \& Mélard, C. 1999. Sibling cannibalism among juvenile vundu under controlled conditions. II. Effect of body weight and environmental variables on the periodicity and intensity of type II cannibalism. Journal of Fish Biology, 54: 106-118.

Berlinsky, D.L., Taylor, J.C., Howell, R.A., Bradley, T.M. \& Smith, T.I. 2004. The effects of temperature and salinity on early life stages of black sea bass Centropristis striata. Journal of the World Aquaculture Society, 35: 335-344.

Borcato, F.L., Bazzoli, N. \& Sato, Y. 2004. Embriogenesis and larval ontogeny of the Pirugordura, Leporinus piau (Fowler) (Pisces, Anostomidae) after induced spawning. Revista Brasileira de Zoologia, 21: 117-122.

Brown, J.A. 1986. The development of feeding behaviour in the lumpfish, Cyclopterus lumpus. Journal of Fish Biology, 29: 171-178.

Ching, F.F., Nakagawa, Y., Kato, K., Murata, O. \& Miyashita, S. 2012. Effects of delayed first feeding on the survival and growth of tiger grouper, Epinephelus fuscoguttatus (Forsskål, 
1775), larvae. Aquaculture Research, 43: 303310.

Chong, A.S., Ishak, S.D., Osman, Z. \& Hashim, R. 2004. Effect of dietary protein level on the reproductive performance of female swordtails Xiphophorus helleri (Poeciliidae). Aquaculture, 234: 381-392.

Cloutier, R., Lambrey de Souza, J., Browman, H.I. \& Skiftesvik, A.B. 2011. Early ontogeny of the Atlantic halibut Hippoglossus hippoglossus head. Journal of Fish Biology, 78: 1035-1053.

Dou, S., Masuda, R., Tanaka, M. \& Tsukamoto, K. 2002. Feeding resumption, morphological changes and mortality during starvation in Japanese flounder larvae. Journal of Fish Biology, 60: 1363-1380.

Duarte, C.M. \& Alcaraz, M. 1989. To produce many small or few large eggs: a size-independent reproductive tactic of fish. Oecologia, 80: 401404.

Dulmaa, A. 1999. Fish and fisheries in Mongolia. In: Fish and Fisheries at Higher Altitudes: Asia. T. Petr (Ed.). Food and Agricultural Organization of the United Nations, Rome, pp. 187-236.

FAO (Food and Agriculture Organization). 2010. Cultured Aquatic Species Information Programme: FAO Silurus asotus [WWW Document]. URL http://www/fao.org/home/en/ (accessed 10.3.20).

Ferosekhan, S., Sahoo, S.K., Giri, S.S., Saha, A. \& Paramanik, M. 2015. Embryonic and larval development of yellow tail catfish, Pangasius pangasius. Journal Aquaculture Research Development, 6(6): 343.

Finn, R.N., Fyhn, H.J. \& Evjen, M.S. 1995. Physiological energetics of developing embryos and yolk-sac larvae of Atlantic cod (Gadus morhua). I. respiration and nitrogen metabolism. Marine Biology, 124: 355-369.

Fukuhara, O. 1986. Morphological and functional development of Japanese flounder in early life stage. Bulletin Japanese Society of Fisheries Science, 52: 81-91.

Gill, H.W., Lee, T.H. \& Park, I.S. 2017. Effects of cryoprotectants and diluents on the cryopreservation of spermatozoa from Far Eastern Catfish, Silurus asotus. Development \& Reproduction, 21: 79-91.

Gisbert, E., Williot, P. \& Castello-Orvay, F. 2000. Influence of egg size on growth and survival of early stages of Siberian sturgeon (Acipenser baeri) under small scale hatchery conditions. Aquaculture, 183: 83-94.

Green, B.S. \& Fisher, R. 2004. Temperature influences swimming speed, growth and larval duration in coral reef fish larvae. Journal of Experimental Marine Biology and Ecology, 299: 115-132.
Haylor, G.S. \& Mollah, M.F. 1995. Controlled hatchery production of African catfish, Clarias gariepinus: the influence of temperature on early development. Aquatic Living Resources, 8: 431-438.

Hodson, P.V. \& Blunt, B.R. 1986. The effect of time from hatch on the yolk conversion efficiency of rainbow trout, Salmo gairdneri. Journal of Fish Biology, 29: 37-46.

Houde, E.D. 1974. Effects of temperature and delayed feeding on growth and survival of larvae of three species of subtropical marine fishes. Marine Biology, 26: 271-285.

Huckstorf, V. 2012. Silurus asotus. The IUCN Red List of Threatened Species 2012 [WWW Document]. URL https://www.iucnredlist.org/ (accessed 10.3.20).

Ing, N.S. \& Chew, H.H. 2015. Nutritional transition period in early larvae Clarias gariepinus. Malaysian Journal of Analytical Sciences, 19: 1120-1130.

Ishibashi, N. 1974. Feeding, starvation and weight changes of early fish larvae in the early life history of fish. In: The Early Life History of Fish. J.H.S. Blaxter (Ed.). Springer, Berlin, pp. 339-344.

Iwai, T. 1980. Sensory anatomy and feeding of fish larvae. In fish behavior and its use in the capture and culture of fishes. ICLARM Conference Proceedings, 5: 124-145.

Izquierdo, M.S., Fernandez-Palacios, H. \& Tacon, A.G.J. 2001. Effect of broodstock nutrition on reproductive performance of fish. Aquaculture, 197: 25-42.

Jordaan, A. \& Kling, L.J. 2003. Determining the optimal temperature range for Atlantic cod (Gadus morhua) during early life, in: Proceedings of the 26th Annual Larval Fish Conference Bergen. Norway, Institute of Marine Research, pp. 45-62.

Kailasam, M., Thirunavukkarasu, A.R., Selvaraj, S. \& Stalin, P. 2007. Effect of delayed initial feeding on growth and survival of Asian sea bass Lates calcarifer (Bloch) larvae. Aquaculture, 271: 298-306.

Katano, O., Nakamura, T. \& Yamamoto, S. 2005. Prey fish selection by Far Eastern catfish Silurus asotus and largemouth bass Micropterus salmoides. Fisheries Science, 71: 862-868.

Kim, D.S., Cho, H.J., Park, I.S., Choi, G.C. \& Nam, Y.K. 2001. Cytogenetic traits and gonad development of induced triploidy in far eastern catfish (Silurus asotus). Gene and Genomic, 23: 55-2.

Kim, I.S., Choi, Y., Lee, C.L., Lee, Y.J., Kim, B.J. \& Kim, J.H. 2005. Illustrated book of Korean Fishes. Kyok-Hak Pub Co., Korea. 455 pp. 
Lubzens, E., Sagie, G., Minkoff, G., Meragelman, E. \& Schneller, A. 1984. Rotifers (Brachionusplicatilis) improve growth-rate of carp (Cyprinus-carpio) larvae. Bamidgeh, 36: 41-46.

Maehata, M. 2002. Stereotyped sequence of mating behavior in the Far Eastern catfish, Silurus asotus, from Lake Biwa. Ichthyological Research, 49: 202-205.

Mashaii, N., Rajabipour, F., Mohammadi, M., Sarsangi, H., Bitaraf, A., Hossein-Zadeh, H. \& Sharif-Rohani, M. 2016. Reproduction of nile tilapia, Oreochromis niloticus in brackish water. Journal of Applied Aquaculture, 28: 1-8.

Mat Nawang, S.U.S., Ching, F.F. \& Senoo, S. 2019. Comparison on growth performance, body coloration changes and stress response of juvenile river catfish, Pangasius hypophthalmus reared in different tank background colour. Aquaculture Research, 50: 2591-2599.

Matsumoto, S., Morioka, S. \& Kumagai, S. 2001. Development of African catfish Clarias gariepinus larvae during the transitional phase between endogenous and exogenous energy intake, in: Proceedings of the Lake Malawi Fisheries Management Symposium. Department of Fishery, Lilongwe, pp. 227-232.

McGurk, M.D. 1986. Natural mortality of marine pelagic fish eggs and larvae: role of spatial patchiness. Marine Ecology Progress Series, 34: 227-242.

Meijide, F.J. \& Guerrero, G.A. 2000. Embryonic and larval development of a substrate-brooding cichlid Cichlasoma dimerus (Heckel, 1840) under laboratory conditions. Journal of Zoology, 252: 481-493.

Mollah, M.F.A., Islam, M.S., Faroque, M.A.A. \& Khan, M.H.K. 1999. Minimization of cannibalism of African catfish (Clarias gariepinus Burchell) larvae in indoor culture system. Bangladesh Journal of Fisheries Research, 3: 181-186.

Muchlisin, Z.A. 2017. Potency of freshwater fishes in Aceh waters as a basis for aquaculture development program [Potensi ikan air tawar di Aceh sebagai dasar untuk pengembangan budi daya]. Jurnal Iktiologi Indonesia, 13: 91-96.

Muchlisin, Z.A. \& Hashim, R. 2006. Influence of dietary protein levels on growth and egg quality in broodstock female bagrid catfish (Mystus nemurus Cuv. \& Val.). Aquaculture Research, 37: 416-418.

Mukai, Y., Tuzan, A.D., Lim, L.S., Wahid, N., Sitti Raehanah, M.S. \& Senoo, S. 2008. Development of sensory organs in larvae of African catfish Clarias gariepinus. Journal of Fish Biology, 73: 1648-1661.
Mukai, Y., Tuzan, A.D., Shaleh, S.R.M. \& ManjajiMatsumoto, B.M. 2010. Development of sensory organs and changes of behavior in larvae of the sutchi catfish, Pangasianodon hypophthalmus. Fisheries Science, 76: 921-930.

Mun, S.J., Yim, H.S., Han, K.H. \& Park, J.M. 2017. Morphological development of eggs, larvae and juveniles of the Far Eastern catfish, Silurus asotus in Korea (Pisces: Siluridae). Development \& Reproduction, 21: 399.

Ooi, S.Y. 2010. Morphological Development of Bagrid Catfish, mystus nemurus at Early Larval Stage (Ph.D). Universiti Malaysia Sabah.

Park, I.S., Im, J.H. \& Hur, J.W. 2004. Morphometric characteristics of catfish (Siluridae) in Korea. Koreaan JIchthyol, 16: 223-228.

Puvaneswari, S., Marimuthu, K., Karuppasamy, R. \& Haniffa, M.A. 2009. Early embryonic and larval development of Indian catfish, Heteropneustes fossilis. EurAsian Journal of BioSciences, 3(1): 84-96.

Qin, J. \& Hillier, T. 2000. Live food and feeding ecology of larval snapper (Pagrus auratus). Fisheries Research and Development Commission.

Rahmah, S., Yamamoto, S., Nakagawa, Y., Kato, K., Senoo, S. \& Murata, O. 2011. Development of morphology, sensory organs and behavior of larval bagrid catfish Mystus nemurus. Aquaculture Science, 59: 443-450.

RamezaniFard, E., Kamarudin, M.S., Harmin, S.A., Saad, C.R., Abd Satar, M.K. \& Daud, S.K. 2011. Ontogenic development of the mouth and digestive tract in larval Malaysian mahseer, Tor tambroides Bleeker. Journal of Applied Ichthyology, 27: 920-927.

Rijnsdorp, A.D., Peck, M.A., Engelhard, G.H., Möllmann, C. \& Pinnegar, J.K. 2009. Resolving the effect of climate change on fish populations. ICES Journal of Marine Science, 66: 15701583.

Rogers, B.A. \& Westin, D.T. 1981. Laboratory studies on effects of temperature and delayed initial feeding on development of striped bass larvae. Transactions of the American Fisheries Society, 110: 100-110.

Rønnestad, I., Yúfera, M., Ueberschär, B., Ribeiro, L., Sæle, Ø. \& Boglione, C. 2013. Feeding behaviour and digestive physiology in larval fish: current knowledge, and gaps and bottlenecks in research. Reviews in Aquaculture, 5: S59-S98.

Samad, M.A., Hossain, M.T. \& Rahman, B.M.S. 2013. Present status of broodstock management at carp hatcheries in Jessore. Journal of the Bangladesh Agricultural University, 11: 349358. 
Sato, M. \& Katagiri, Y. 1966. Regeneration of the mandibular barbels of the fry of the catfish, Parasilurus asotus, and comparison of histological structure of the mandibular barbels of three catfishes inhabiting Lake Biwa. Japanese Journal of Ichthyology, 13: 169-175.

Standen, E.M. \& Lauder, G.V. 2005. Dorsal and anal fin function in bluegill sunfish Lepomis macrochirus: three-dimensional kinematics during propulsion and maneuvering. Journal of Experimental Biology, 208: 2753-2763.

Swanson, C. 2005. Early development of milkfish: effects of salinity on embryonic and larval metabolism, yolk absorption and growth. Journal of Fish Biology, 48: 405-421.
Watanabe, W.O., Feeley, M.W., Ellis, S.C. \& Ellis, E.P. 1998. Light intensity and salinity effects on eggs and yolk sac larvae of the summer flounder. The Progressive Fish-Culturist, 60: 9-19.

Yang, W.S., Gil, H.W., Yoo, G.Y. \& Park, I.S. 2015. Identification of skeletal deformities in Far Eastern Catfish, Silurus asotus under indoor aquaculture condition. Development \& Reproduction, 19: 153-161.

Yoseda, K., Dan, S., Sugaya, T., Yokogi, K., Tanaka, M. \& Tawada, S. 2006. Effects of temperature and delayed initial feeding on the growth of Malabar grouper (Epinephelus malabaricus) larvae. Aquaculture, 256: 192-200. 
